\title{
Katriina Tapanila
}

\section{Työn merkityksellisyyden rakentaminen ja jännitteet muuttuvassa yliopistossa}

\section{Tiivistelmä}

Työn merkityksellisyyden rakentamista ohjaa moraalinen kehys; se auttaa ihmistä valitsemaan asioita, joihin hän sitoutuu. Yksilön moraaliseen kehykseen voi kytkeytyä hänen ammatilleen ominainen eetos. Tarkastelen akateemista professiota, jonka työskentelyedellytyksiä viime vuosikymmeninä toteutetut yliopistouudistukset ovat muovanneet. Kysyn, miten kasvatustieteitä, lääke- ja biotieteitä ja kielitieteitä edustavat tutkija-opettajat suhtautuvat yritysmäisen yliopiston arvostamiin asioihin ja sen heille asettamiin vaatimuksiin sekä millaisia jännitteitä nämä suhtautumistavat ilmentävät liittyen työn merkityksellisyyden rakentamiseen. Aineistona ovat teemakirjoittamisen menetelmällä kerätyt tutkija-opettajien kuvaukset suhteestaan työhönsä ja yliopistossa tapahtuneisiin muutoksiin. Tunnistin aineistosta viisi erilaista suhtautumistapaa: 1) yritysmäisen yliopiston vastustus, 2) työssä kuormittuminen ja resurssipulasta kärsiminen, 3) toimintaedellytysten yleinen analysointi ja kritisointi, 4) tyytyväisyys yliopistotyössä ja 5) itsenäinen, vaikutusvaltainen toimijuus. Eroja suhtautumistavoissa näyttivät tuottavan opetus- ja tutkimustyön resurssien epätasainen jakautuminen sekä tutkija-opettajien erilaiset vaikutusmahdollisuudet ja kokemukset arvostuksen saamisesta työssään. Yliopisto todennäköisesti kykenisi toteuttamaan yhteiskunnallista palvelutehtäväänsä monipuolisemmin, jos arvostusta osoitettaisiin ja resursseja jaettaisiin tasapuolisemmin eri tieteenaloilla ja erilaisissa positioissa tehtävälle yliopistotyölle. 


\section{Akateemisen työn merkityksellisyys viime vuosikymmenten yliopistouudistuksissa}

Ihminen pyrkii kokemaan työssään merkityksellisyyttä (Cohen-Meitar ym. 2009), joten hän on taipuvainen rakentamaan sitä työssä tavoittelemiensa asioiden kautta. Työn merkityksellisyydellä tarkoitetaan yksilön oman työn tavoitteiden ja päämäärien arvoa, jonka hän on arvioinut omien ihanteidensa ja standardiensa pohjalta (May ym. 2004). Filosofi Charles Taylorin (1989) mukaan yksilön identiteettiä määrittävä moraalinen kehys auttaa yksilöä arvioimaan, mikä on hyvää ja arvokasta, miten hänen tulisi toimia ja mitä kannattaa tai vastustaa (Taylor 1989, 27-28). Merkityksellisyyden toteutuminen omassa elämässä on yksi moraalisen kehyksen ulottuvuus (Taylor 1989, 15; Henkel 2005, 157). Moraalinen kehys on siis eräänlainen suunnannäyttäjä, joka ohjaa merkityksellisyyden rakentamista omassa työssä.

Ihanteet ja arvostukset, joiden pohjalta työn merkityksellisyyttä rakennetaan, eivät kuitenkaan ole pelkästään yksilöllisiä, vaan niitä leimaa ammatillinen eetos. Sillä tarkoitetaan ammattilaisten ajattelua ja arkipäivän toimintaa ohjaavia ammatillisia rakenteita, käytänteitä ja uskomuksia, joita tuotetaan ja uusinnetaan sosiaalisesti sekä välitetään uusille ammattilaissukupolville (Kallio 2015, 58, 93). Tarkastelen tässä artikkelissa työn merkityksellisyyden rakentamista yliopistossa työskentelevien tutkijoiden ja opettajien näkökulmasta. Näiden yliopistotyön ammattilaisten voi katsoa kuuluvan akateemiseen professioon. Akateemisessa professiossa sitoutuminen tieteenalaan on usein vahvaa, ja siksi professiota voidaan pitää epäyhtenäisenä (esim. Kolsaker 2008, 516; McInnis 2010, 149-50). Yliopistossa työskentelevien tutkijoiden ja opettajien on kuitenkin nähty tieteenalasta riippumatta jakavan työhön liittyviä arvoja, kuten yhtäältä yhteiseen hyvään sitoutuminen, opiskelijoista huolehtiminen, autonomia, kriittisyys ja totuuden tavoittelu (Kogan ym. 1994, 28-29; Chown 1996, 148; Hakala 2009, 174; McInnis 2010, 149-50), mutta toisaalta myös kilpailullisuus (Ylijoki 2014, 70). Nämä arvot luovat pohjaa akateemista ammattikuntaa yhdistävälle ammatilliselle eetokselle.

Viime vuosikymmeninä Suomessa ja monessa muussakin Euroopan maassa toteutetut yliopistouudistukset ovat muovanneet akateemisen työn tekemisen edellytyksiä ja vaatimuksia. Yliopistojen muodollista autonomiaa suhteessa valtioon on lisätty, jolloin yliopiston henkilöstön suhde työnantajaansa on muuttunut. Suomessa vuonna 2010 toteutetun yliopistouudistuksen myötä yliopistot muuttuivat valtion 
tilivirastoista itsenäisiksi oikeushenkilöiksi. Samalla yliopistossa työskentelevät tutkijat ja opettajat muuttuivat valtion virkamiehistä yliopistotyönantajan kontrolloimiksi työntekijöiksi. (Kaukonen \& Välimaa 2010, 18-19; Kallio ym. 2016; Siekkinen 2019,33 .) Yliopistossa vallitsevien työskentelyolosuhteitten ja -kulttuurin muutoksen voi olettaa vaikuttavan tutkijoiden ja opettajien mahdollisuuksiin rakentaa työnsä merkityksellisyyttä.

Julkinen valta ja elinkeinoelämä odottavat yliopistoilta nykyisin yhä suoremmin taloudellista hyötyä tuottavaa toimintaa, kuten innovaatioita ja nopeasti sovellettavia tieteellisiä tuloksia (Björn ym. 2017). Pystyäkseen vastaamaan näihin odotuksiin yliopistot ovat uudistaneet johtamiskäytäntöjään yritysmaailman oppien mukaan ja ottaneet käyttöön suorituskykyä mittaavia järjestelmiä kontrolloimaan yliopiston tutkijoiden ja opettajien työtä (Kallio ym. 2016, 689). Yliopiston muutosta tarkastelevassa tutkimuskirjallisuudessa on käytetty usein yritysmäisen yliopiston (entrepreneurial university) käsitettä. Käsitteen merkitys ei ole yksiselitteinen; sitä on käytetty toisaalta kuvaamaan yliopistojen sopeutumisedellytyksiä muuttuvassa ympäristössä (esim. Clark 1998) ja toisaalta johtajakeskeisen eetoksen ja markkinaajattelun vahvistumista yliopistossa sekä yliopistojen kasvanutta vastuuta toimintansa rahoituksesta (Subotszky 1999, 402). Jenni Kankaanpää $(2013,62)$ on käyttänyt yritysmäisen yliopiston käsitettä kuvaamaan yliopiston ja sen toimintaedellytysten muutosta erityisesti 2000-luvulla: yritysmäisten toimintatapojen tuomista yliopistoon ja yrityksille tyypillisten tehokkuus-, hyöty- ja tuottavuusodotusten kohdistamista yliopistoihin. Käytän yritysmäisen yliopiston käsitettä tässä artikkelissa Kankaanpään tavoin kiteyttämään muutokset, jotka ovat muovanneet yliopistoa yritysmäiseen suuntaan. Tarkoitan yritysmäisellä yliopistolla yliopistotyönantajaa, joka pyrkii yritysmäisten toimintatapojen avulla vastaamaan edellä mainittuihin odotuksiin.

Tutkijoita ja opettajia yhdistävästä ammatillisesta eetoksesta huolimatta tieteenalojen on nähty muodostavan akateemisia heimoja, joilla on erilaiset tavoitteet, arvot ja toimintatavat (Becher 1989; Ylijoki 1998). Eri tieteenalojen edustajien on havaittu suhtautuneen eri tavoin yliopistossa tapahtuviin muutoksiin (Slaughter \& Leslie 1997). Yliopistotyön muutosta tutkineiden Risto Rinteen ja hänen kollegoittensa (2012) tutkimuksessa lääketiedettä edustava yliopistohenkilöstö suhtautui uuteen yliopistopolitiikkaan, kuten tulosvastuuseen ja yliopistojen yritysmäistymiseen, muita tieteenaloja myönteisemmin. Kaikkein kielteisimmin uuden yli- 
opistopolitiikan koki humanistisia tieteitä, muun muassa kielitieteitä, edustava yliopistohenkilöstö. Kasvatustieteilijät sijoittuivat suhtautumistavaltaan lääketieteen ja humanististen tieteiden väliin. (Rinne ym. 2012, 107-112.) Tässä artikkelissa tarkastelen juuri kasvatus-, lääke- ja kielitieteitä edustavien tutkijoiden ja opettajien suhtautumistapoja yritysmäisen yliopiston arvostamiin asioihin ja sen heidän työlleen asettamiin vaatimuksiin, jotta tavoittaisin mahdollisimman laajasti erilaisia näkökulmia yliopistotyön merkityksellisyyteen.

Akateemista työtä käsittelevässä tutkimuskirjallisuudessa ei ole tyypillisesti puhuttu työn merkityksellisyyden rakentamisesta, vaan yliopistotyötä ja sen muutosta on jäsennetty muun muassa akateemisen identiteetin käsitteen avulla (esim. Hakala 2009; McInnis 2010; Ylijoki \& Ursin 2013). Yliopiston muutosta voi kuitenkin olla hyödyllistä tarkastella myös työn merkityksellisyyden rakentamisen näkökulmasta. Tutkija-opettajilla voi olla yksilöllisiä tapoja suhtautua työn muutokseen, eivätkä ne välttämättä ole sidoksissa kollektiiviseen akateemiseen identiteettiin. Tarkastelemalla työn merkityksellisyyden rakentamista tutkija-opettajien oman moraalisen kehyksen ohjaamana voi tehdä näkyväksi heidän yksilöllisiä ja siten moninaisia suhtautumistapojaan muuttuvaan yliopistotyöhön.

\section{Akateeminen eetos yliopistotyön merkityksellisyyden rakentamisessa}

Tietyn profession edustajat jakavat tyypillisesti keskenään työn normatiivisen arvojärjestelmän, jota he edistävät itseään ja toisiaan varten (Evetts 2013, 782). Sitoutumalla tähän arvojärjestelmään he pyrkivät ylläpitämään professionsa asemaa suhteessa muihin toimijaryhmiin, kuten työnantajiin ja asiakkaisiin. Korkeasti koulutetun profession edustajat perustelevat usein itsenäistä asemaansa tuomalla esiin omistautumistaan transsendenteille arvoille, kuten totuudelle, kauneudelle, sivistykselle tai oikeudenmukaisuudelle, sen sijaan, että he vain suorittaisivat heiltä vaaditut tehtävät. (Freidson 1999, 127.) Näihin arvoihin kytkeytyy kyseisen profession ammatillinen eetos (Kallio 2015), joka ohjaa siihen sitoutuneiden ammattilaisten ajattelua ja toimintaa. Yliopistossa tutkimus- ja opetustyötä tekevien kohdalla puhutaan akateemisesta eetoksesta (Kallio 2015, 90). Sitä voi pitää osana siihen sitoutuneiden tutkijoiden ja opettajien moraalista kehystä (Taylor 1989), joka auttaa heitä 
punnitsemaan, mitä asioita heidän tulisi kannattaa tai vastustaa työnsä merkityksellisyyttä rakentaessaan.

Tutkimuskirjallisuudessa on käyty keskustelua siitä, missä määrin profession edustajat palvelevat yhteistä hyvää ja missä määrin omia intressejään. Ammattilaisten eli profession edustajien on katsottu olevan taipuvaisia palvelemaan ensisijaisesti muiden etuja omiensa sijaan (Parsons 1939, 458). Myös akateemisen profession yhtenä erityispiirteenä on pidetty sitä, että se asettaa muiden palvelemisen ja tiedon tavoittelun oman etunsa edelle (esim. McInnis 2010, 149-150). Parsons (1939) vertaa altruisteina nähtyjä ammattilaisia liikemiehiin, joiden on puolestaan katsottu tavoittelevan egoistisesti omia etujaan muiden eduista välittämättä. Hän kuitenkin pitää tällaista vastakkainasettelua liian yksinkertaistavana: sekä ammattilaiset että liikemiehet pyrkivät menestymään eli saavuttamaan tavoitteensa omassa toiminnassaan ja saamaan tunnustusta oman ammatillisen ryhmänsä sisällä, vaikka he tavoittelevat näitä asioita eri tavoin ja erilaisissa normatiivisissa ja institutionaalisissa puitteissa. (Parsons 1939, 458-465.)

Vaikka eri tieteenalojen edustajat ovat suhtautuneet yliopiston yritysmäistymiseen eri tavoin (Slaughter \& Leslie 1997; Rinne ym. 2012), tieteenaloja yhdistävän perinteisen akateemisen eetoksen on nähty olevan huonosti sovitettavissa yhteen yritysmäiselle yliopistolle ominaisen tehokkuusajattelun kanssa (Kallio 2015, 5). Yritysmäisen yliopiston toiminta pohjautuu managerialismiin, joka yliopistokontekstissa tarkoittaa sitä, että yliopiston johdolle luodaan mahdollisuuksia kontrolloida ja säädellä akateemista työtä, jolloin valtaa siirretään akateemiselta yhteisöltä johtajille (Gordon \& Whitchurch 2010; Shepherd 2018; Carvalho \& Videira 2019). Tämä on vastakkainen ajattelutapa verrattuna professionalismiin, jossa työn organisointi perustuu profession hallussa olevaan asiantuntemukseen ja sen omaan työhönsä kohdistamaan kontrolliin, sillä vain käytännön toimijoiden - eli profession edustajien - nähdään voivan ymmärtää kompleksisen työn vaatimukset, prosessit ja tuotokset (Freidson 2001; Evetts 2013).

Managerialismi perustuu ajatukselle, että tuottavuustavoitteet saavutetaan, kun eliminoidaan käytännön toimijoiden omasta harkintakyvystä aiheutuva ennakoimattomuus korvaamalla se johtamisjärjestelmällä, joka rationalisoi tehtävät, organisoi ne muodollisten sääntöjen mukaan ja valvoo työsuoritteita (Freidson 1999, 126). Johtamisjärjestelmät yhdistettynä kasvaneeseen kilpailuun rahoituksesta ovat luoneet yliopiston tutkijoille ja opettajille lisää paineita tuottaa enemmän ja kor- 
keatasoisempia tutkintoja ja julkaisuja sekä lisätä työnsä yhteiskunnallista vaikuttavuutta (Ylijoki \& Ursin 2013, 1136).

Akateemisen työn monimutkaistuminen ja pirstoutuminen ulkopuolelta tulevien odotusten takia on aiheuttanut sen, että akateemisen profession on yhä vaikeampaa ylläpitää työhön perinteisesti liittynyttä itsehallintaa ja kontrollia. Suoritusten valvontaan liittyvän hallinnollisen työn lisääntyminen on kasvattanut tutkijoiden ja opettajien työmäärää ja heikentänyt heidän kokemustaan oman työn hallinnasta ja autonomiasta. Muuttuneiden johtamiskäytäntöjen myötä lisääntyneet velvoitteet ovat rajanneet tutkijoiden ja opettajien mahdollisuuksia tehdä omaehtoisia valintoja työssään. (McInnis 2010, 155.) Kun kasvaneen kontrollin lisäksi yliopistohenkilöstön työsuhteet ovat muuttuneet epävarmemmiksi, yliopiston tutkijoiden ja opettajien aseman on nähty heikentyneen ja heidän muuttuneen "johdetuiksi ammattilaisiksi" (managed professionals) (Rhoades 1998; Ylijoki \& Ursin 2013, 1136). Tällöin tutkijaopettajat eivät välttämättä voi rakentaa työnsä merkityksellisyyttä oman moraalisen kehyksensä ohjaamana, vaan heidän on toimittava yliopiston asettamien tavoitteiden mukaan, vaikka ne olisivat ristiriidassa heidän omien arvojensa tai akateemisen eetoksen kanssa.

Toisaalta managerialistiseen ympäristöön sopeutumisen on nähty vahvistaneen akateemista identiteettiä (McInnis 2010,148). Siekkinen $(2019,63)$ näkee managerialismin vahvistumisesta huolimatta akateemisella professiolla olevan edelleen valtaa yliopistossa ja mahdollisuuksia suojella omia perinteisiä toimintatapojaan ja arvojaan. Kallio (2015, 89-90) katsoo akateemisen profession sitoutuvan edelleen voimakkaasti yhteiseen arvomaailmaan ja eetokseen, minkä takia professio vastustaa yhtenä rintamana ulkoapäin tulevia muutoksia. Ylijoki ja Ursin (2013) puolestaan kuvaavat yliopistojen rakenteellisten uudistusten aiheuttamaa akateemisten identiteettien polarisoitumista. Heidän tarkastelemansa narratiivit ilmensivät käsityksiä siitä, millaista on olla tutkija tai opettaja nykypäivän yliopistossa. Osa narratiiveista kertoi uudistusten vastustamisesta, työskentelyedellytysten huononemisesta ja epävarmuudesta, kun taas osa kuvasi menestystä, oman aseman vahvistumista ja uudistusten tuomia uusia mahdollisuuksia. (Ylijoki \& Ursin 2013.) 


\section{Aineisto ja menetelmät}

Tässä artikkelissa kysyn: 1) miten kasvatus-, lääke-, bio- ja kielitieteitä edustavat tutkija-opettajat suhtautuvat yritysmäisen yliopiston heille asettamiin vaatimuksiin ja sen arvostamiin asioihin, sekä 2) millaisia työn merkityksellisyyden rakentamiseen liittyviä jännitteitä nämä suhtautumistavat ilmentävät. Aineisto koostuu vastauksista internetpohjaiseen e-lomakkeeseen, jossa yliopistossa työskenteleviä tutkija-opettajia pyydettiin kirjoittamaan kuvauksia suhteestaan omaan työhönsä. Keräsin aineiston osana väitöstutkimustani, joka tarkastelee työn merkityksellisyyden rakentumista yliopistouudistusten ja muuttuvien yliopistotyön vaatimusten kontekstissa (ks. myös Tapanila 2020; Tapanila ym. 2020). Artikkeli koskee väitöstutkimuksen yhtä osatutkimusta, joten hyödynnän tässä vain osaa kerätystä aineistosta.

Tutkija-opettajilla tarkoitan henkilöitä, joiden pääasiallinen työtehtävä yliopistossa on tutkimus ja opetus tai toinen niistä. Tähän ryhmään luin seuraavat yliopistossa käytössä olevat tehtävänimikkeet: apulaisprofessori, professori, projektitutkija, tutkijatohtori, tutkija, yliopistonlehtori, yliopisto-opettaja ja yliopistotutkija. Nämä nimikkeet esiintyivät lähes kaikissa kohteeksi valituissa tieteenalayksiköissä, ja ne edustavat suurinta osaa yliopistojen tutkimus- ja opetushenkilöstöstä.

Lähetin lomakkeen vastattavaksi kahden suurehkon suomalaisen yliopiston ("yliopisto A" ja "yliopisto B") kasvatustieteiden, lääketieteen ja kielitieteiden tiedekunnassa työskenteleville tutkija-opettajille lokakuussa 2017. Yliopisto A:ssa otin mukaan lisäksi biotieteitä edustavat tutkija-opettajat, sillä he kuuluivat samaan tiedekuntaan lääketieteen kanssa ja biotieteet luonnontieteinä lukeutuvat lääketieteen tavoin niin sanottuihin koviin tieteisiin. Lomakkeen sai vastattavakseen yhteensä 610 tutkija-opettajaa, noin 300 kummastakin yliopistosta. Laadin kullekin kuudelle kohteena olleelle tieteenalayksikölle erillisen lomakkeen, jotta eri tieteenalayksiköitä edustavat vastaukset pysyisivät teknisesti erillään toisistaan. Lomakkeissa kysyttiin taustatietoina vastaajan ikäryhmää, sukupuolta ja vuotta, jolloin hän on aloittanut ensimmäisessä työsuhteessaan jossain suomalaisessa yliopistossa. Muita taustatietoja ei anonymiteetin säilymisen turvaamiseksi kysytty.

Sain vastauksia yhteensä 117, joten koko aineiston vastausprosentiksi muodostui noin 19. Vastaajista 34 prosenttia edusti kasvatustieteitä, 48 prosenttia lääke- ja 
biotieteitä ja 18 prosenttia kielitieteitä. Enemmistö vastaajista, 62 prosenttia, oli naisia, ja suurin ikäryhmä oli 40-55-vuotiaat, joita oli 44 prosenttia vastaajista.

Sovelsin aineistonkeruussa teemakirjoittamisen menetelmää. Siinä tutkittavat kertovat tiettyyn teemaan liittyvistä kokemuksistaan kuten teemahaastattelussa mutta ilmaisevat itseään puhumisen sijaan kirjoittamalla (Apo 1995, 173-174; Laajalahti 2015). Teemakirjoittamisen metodologisena etuna on, että se tuo esiin tutkittavien jäsennykset siten, että tutkija on vaikuttanut niihin mahdollisimman vähän (Apo 1995, 176). Sen vuoksi oletin, että työlle annetut merkitykset ja työssä tavoiteltavat asiat tulisivat tutkija-opettajien itse tuottamissa teksteissä esiin mahdollisimman autenttisina ja moninaisina. Lisäksi menetelmä mahdollisti aineiston keräämisen laajemmalta kohdejoukolta kuin esimerkiksi haastattelututkimuksessa, mikä osaltaan edisti aineiston moninaisuutta. Oletuksenani oli, että omista kokemuksista kirjoittaminen itsenäisesti soveltuisi tutkimuksen kohderyhmälle, jonka työhön kirjoittaminen kuuluu olennaisena osana.

Pyysin vastaajia kuvailemaan suhtautumistaan omaan työhönsä yliopistossa ja nykyistä yliopistoaan tai tieteenalayksikköään työskentely-ympäristönä tai työpaikkana. Kirjoittamista ohjasi seitsemän avokysymystä, joista tämän artikkelin kannalta olennaisimpia ovat seuraavat: "Miten koet pystyväsi toteuttamaan sinulle tärkeitä asioita yliopistossasi tai tieteenalayksikössäsi työskennellessäsi ja mitkä asiat tähän vaikuttavat?" "Ovatko mahdollisuutesi toteuttaa sinulle tärkeitä asioita yliopistossasi/tieteenalayksikössäsi työskennellessäsi mielestäsi muuttuneet viimeisten 5-10 vuoden aikana ja jos ovat, niin miten?" "Millaisia asioita yliopistossasi tai tieteenalayksikössäsi mielestäsi arvostetaan, ja millainen vaikutus niillä on sinuun tai sinun työhösi?" Aineistoa kertyi yhteensä noin 140 sivua. Yksittäisten vastaajien kirjoittamien kuvausten pituus vaihteli vajaasta sivusta kolmeen sivuun.

Koska kuvaukset olivat narratiivista, kerrontaan perustuvaa aineistoa, sovellan aineiston analyysissa narratiivista lähestymistapaa. Sen mukaan ihmiset rakentavat identiteettiään ja maailmaa koskevaa tietoaan narratiivisesti; narratiivien avulla pyritään tuomaan esiin ihmisten oma tapa antaa asioille merkityksiä (Hänninen 1999, 15, 34; Heikkinen 2001, 116-118). Yksilöiden nähdään puhuvan kokemuksistaan käyttämällä sanoja, käsitteitä ja puheen muotoja, jotka tarjoutuvat heille heidän narratiivisessa ympäristössään (Gubrium \& Holstein 2008). Näitä diskursiivisia elementtejä aineistoni tutkija-opettajat käyttivät omasta työstään puhuessaan. Heidän kirjoittamansa kuvaukset voi käsittää "puheena", jonka avulla he eivät pel- 
kästään kuvaa näkemyksiään ja suhdettaan työhönsä vaan myös rakentavat työnsä merkityksellisyyttä yliopiston heille asettamien vaatimusten ja yliopiston arvostamien asioiden puitteissa.

Aineiston analyysissa pyrin löytämään tutkija-opettajien tapoja jäsentää omia mahdollisuuksiaan työnsä merkityksellisyyden rakentamiseen yritysmäisessä yliopistossa. Analyysin kohteena olivat tutkija-opettajien käyttämät suhteellisen yhtenäiset, toisistaan erotettavissa olevat puhetavat, joissa otetaan kantaa yliopistoympäristössä tapahtuneisiin muutoksiin (ks. myös Ylijoki \& Ursin 2013, 1138). Näiden puhetapojen kautta yritin päästä käsiksi tutkija-opettajien arvoihin, moraaliseen kehykseen ja siihen mahdollisesti liittyvään eetokseen, joiden pohjalta he rakensivat työnsä merkityksellisyyttä. Pyrin samalla hahmottamaan prosessia, jossa tutkijaopettajat suhteuttivat omia arvojaan yliopistossa vallitseviin arvoihin. Kiinnitin huomiota heidän käyttämäänsä sanastoon, jonka katsoin ilmentävän heidän suhtautumistapaansa yritysmäiseen yliopistoon.

Analysoin aineiston laadullisen sisällönanalyysin keinoin tyypittelemällä ja teemoittelemalla (Eskola \& Suoranta 2014). Jaottelin ensin vastaajien kirjoittamat kuvaukset eri tyyppeihin sen mukaan, miten tulkitsin kyseisen vastaajan suhtautuvan yritysmäisen yliopiston asettamiin tavoitteisiin ja sen arvostamiin asioihin. Näin muodostin viisi erilaista suhtautumistapaa. Koska suurin osa kuvauksista edusti tulkintani mukaan useaa eri suhtautumistapaa, tein jaottelun sen suhtautumistavan mukaan, jota katsoin kyseisen kuvauksen selvimmin edustavan. Siten yksittäisiä kuvauksia ei tarvinnut jakaa osiin, mikä mahdollisti niiden kokonaisvaltaisen tarkastelun. Sen jälkeen merkitsin suhtautumistapoihin jaoteltuihin kuvauksiin värikoodeilla muihin suhtautumistapoihin kuuluvat osat, jotka myös huomioin analyysissa.

Tyypittelyn jälkeen teemoittelin eri suhtautumistapoihin jaottelemani kuvaukset tarkentaakseni analyysia. Poimin niistä ainekset, jotka liittyivät yritysmäisen yliopiston asettamiin vaatimuksiin, sen kannattamiin arvoihin sekä asioihin, jotka lisäisivät oman työn merkityksellisyyttä. Näin oli mahdollista saada selvemmin näkyviin suhtautumistapojen sisäistä moninaisuutta ja vaihtelua.

Muodostin analyysissa seuraavat viisi suhtautumistapaa: 1) yritysmäisen yliopiston vastustus, 2) työssä kuormittuminen ja resurssipulasta kärsiminen, 3) tyytyväisyys yliopistotyössä, 4) toimintaedellytysten yleinen analysointi ja kritisointi sekä 5) itsenäinen, vaikutusvaltainen toimijuus. Tulkitsen nämä suhtautumistavat 
tutkija-opettajien erilaisiksi tavoiksi rakentaa työnsä merkityksellisyyttä oman moraalisen kehyksensä ohjaamana yritysmäisen yliopiston tarjoamissa puitteissa.

\section{Tutkija-opettajien suhtautumistavat yritysmäisen yliopiston arvoihin ja sen heille asettamiin vaatimuksiin}

\section{Yritysmäisen yliopiston vastustus}

Tätä suhtautumistapaa edustaneille tutkija-opettajille oli ominaista muita vastaajia vahvempi ja selkeämpi näkemys siitä, millaista yliopistotyön tulisi olla. Heidän mielestään sen tulisi tähdätä tietoon, totuuteen ja sivistykseen - transsendenttisiin arvoihin, joihin he itsekin olivat sitoutuneet. Nämä arvot eivät näiden vastaajien näkemyksen mukaan kuitenkaan toteutuneet nykyisessä yliopistossa, vaan niiden sijaan he näkivät siellä arvostettavan hyvin toisenlaisia asioita, kuten rahoituksen hankkimista sekä julkaisujen ja muiden määrällisten suoritteiden tuottamista. Koska heidän tavoittelemansa asiat näyttäytyivät heille enimmäkseen yritysmäisen yliopiston kannattamien taloudellisten tavoitteiden vastakohtina, he toivat esiin voimakasta jännitettä oman arvomaailmansa ja yliopiston heidän työlleen asettamien vaatimusten välillä:

Yliopistossa vallitsevat työn tavoitteet ja arvostukset ovat enimmäkseen ristiriidassa omien kanssa, joten molempiin pyrkiminen ylläpitää kroonista "hätätilaa".

(yliopisto A, kasvatustieteet, nro 11, nainen, yli 55 vuotta)

Näiden tutkija-opettajien kuvauksissa korostui yliopistotyön muuttuminen huonompaan suuntaan. He kertoivat menneestä ajasta yliopistossa myönteiseen sävyyn: silloin yliopisto pyrki selkeämmin edistämään tiedettä, tutkija-opettajilla oli autonomiaa ja heihin luotettiin. Ylijoen $(2005,571)$ mukaan yliopistouudistusten vastustukseen usein liittyvä nostalgia ei kuitenkaan kuvaa yliopistotyön todellista menneisyyttä, vaan se tarjoaa sosiaalisesti hyväksyttävän välineen nykyisiin olosuhteisiin liittyvien jännitteiden ilmaisemiseen ja akateemisen työn ydinarvojen selkiyttämiseen.

Tätä suhtautumistapaa edustaneet vastaajat näkivät yliopistojen muokkaamisen "kasvuyrityksiksi" ja "tehdasmaisiksi" sekä "rahan merkityksen korostumisen" 
kuitenkin huonontaneen heidän työskentelyedellytyksiään ja vähentäneen heidän kokemustaan työn merkityksellisyydestä. Jotkut vastaajat kyseenalaistivat myös taloudellista voittoa tavoittelevan yliopistotoiminnan eettisen kestävyyden. Koska yliopistotyö näytti olevan heille tärkeä osa omaa identiteettiä, nämä vastaajat kuvasivat yliopiston työskentelyolosuhteiden huononemista hyvin henkilökohtaisena kokemuksena. Kyynistyminen ja pettymys yliopistoon korostui heidän kuvauksissaan:

Muutokset yliopistopolitiikassa ja poliittisessa ilmapiirissä ovat rakennemuutosten kautta ja markkinahengen ja rahan glorifioinnin kautta muuttaneet yliopistoa työpaikkana ihan valtavasti. Tämä ei ole enää se maailma, mihin tulin, eikä se maailma, jossa mennään tiede ja tieto edellä. Se on valtava pettymys. (yliopisto A, lääketiede tai biotieteet, nro 23, nainen, 40-55 vuotta)

Jotkut tätä suhtautumistapaa edustaneista vastaajista kertoivat kokeneensa arvostuksen puutetta työssään. Tämän voi tulkita siten, että he eivät saaneet tunnustusta valinnoilleen, joita heidän moraalinen kehyksensä ja siihen liittyvä akateeminen eetos ohjasi heitä tekemään, sillä ne eivät olleet arvioitavissa yritysmäisen yliopiston käyttämillä suoritusten mittausjärjestelmillä. Näiden vastaajien oli vaikea hyväksyä sitä, että he joutuvat toimimaan työssään managerialististen arvojen ja tavoitteiden mukaan ja että akateemiseen eetokseen perinteisesti kuuluvat autonomia ja vaikutusmahdollisuudet ovat heikentyneet. Yksi kasvatustieteitä edustanut vastaaja kuvasi tilannetta seuraavasti:

Työn merkitystä syö ainainen rahan hakeminen ja lisääntynyt pääoman valta.

Taloudellinen valta tunkeutuu älylliseen työskentelyyn vaivihkaisella mutta toisinaan raa'allakin otteella määrittäen sitä, mitä saa tutkia ja miten entistä enemmän.

(yliopisto A, kasvatustieteet, nro 5, mies, 40-55 vuotta)

Tätä suhtautumistapaa edustaneita vastaajia esiintyi neljässä kuudesta tutkimuksen kohteena olleesta tieteenalayksiköstä, ja puolet heistä edusti yliopisto A:n kasvatustieteellistä tiedekuntaa. Tätä tieteenalayksikköä edustaneet vastaajat halusivat vaalia työssään henkisiä arvoja, kuten eettisyyttä, ekologisuutta ja tasa-arvoa. Perusteluna näiden arvojen edistämiselle yksi mainittua tieteenalayksikköä edustanut vastaaja totesi, että hänelle "kasvatustiede on tässä suhteessa sitoutunut tiedon- ja oppiala". Tässä tieteenalayksikössä voi siis nähdä vallinneen muita tieteenala- 
yksikköjä yhtenäisemmän akateemisen eetoksen, joka ohjasi työn merkityksellisyyden rakentamista.

\section{Työssä kuormittuminen ja resurssipulasta kärsiminen}

Tätä suhtautumistapaa edustaneet tutkija-opettajat kertoivat jännitteistä, joita he kohtasivat pyrkiessään toteuttamaan työssään itselleen tärkeitä asioita ja vastaamaan yliopiston asettamiin odotuksiin. Kun yritysmäisen yliopiston vastustus -suhtautumistavassa koettiin jännitettä omien ja yliopiston edustamien arvojen välillä, tätä suhtautumistapaa puolestaan leimasi puute työnteon konkreettisista edellytyksistä ja resursseista, kuten ajasta, vapaudesta ja rahoituksesta. Nämä vastaajat kertoivat kokevansa, että heillä ei ollut tarpeeksi aikaa tehdä opetus- ja tutkimustyötä, että heidän työtään kontrolloitiin liikaa ja että heidän työnsä tulokset eivät saaneet tunnustusta yliopiston taholta. Heille tärkeät työn sisältöön liittyvät asiat jäivät heidän mielestään toissijaisiksi, kun työtä arvioitiin pääasiallisesti määrällisin mittarein. He kertoivat haluavansa tehdä työnsä hyvin ja laadukkaasti sekä tekevänsä sen vuoksi pitkiä päiviä, jolloin vapaa-aika ja usein myös perhe-elämä joutuivat kärsimään. Tätä suhtautumistapaa edustaneissa kuvauksissa nousi esiin, että vallitsevat työn tekemisen edellytykset eivät mahdollistaneet vastaamista yliopiston asettamiin vaatimuksiin ilman tinkimistä omasta hyvinvoinnista.

Tätä suhtautumistapaa edustaneita vastaajia oli kaikissa tutkimuksen kohteena olleissa tieteenalayksiköissä, mutta erityisen paljon heitä oli opetuspainotteista työtä tekevissä kasvatustieteitä edustavissa tutkija-opettajissa. Nämä kasvatustieteitä edustavat vastaajat kertoivat tavoittelevansa työssään erityisesti hyvää opetusta ja opiskelijoiden kasvattamista. Heidän mielestään opetustyö kuitenkin jäi yritysmäisessä yliopistossa tutkimuksen jalkoihin, eikä sille annettu riittävästi arvostusta ja resursseja. Opetus oli näille vastaajille henkilökohtaisesti tärkeää, mutta he pitivät suuria opetusmääriä kuormittavina. Lisäksi he kuvasivat riittämättömyyden tunnetta siitä, ettei heillä ollut tarpeeksi voimavaroja tehdä tutkimusta opetuksen ohella:

Yliopistolaitoksen viimeaikainen kehitys on vienyt suuntaan, joka nakertaa työntekijöiden mahdollisuuksia tehdä työtään hyvin, laadukkaasti ja paneutuen - siis parhaalla mahdollisella tavalla. Tämä on syönyt merkittävästi omaa motivaatiotani. 
Ainakin omasta opetuspainotteisesta työstäni on tullut liukuhihnatyötä. Ryhmäkoot ovat paisuneet naurettaviksi (esim. lähes sadan hengen seminaariryhmät), perusopinnot organisoidaan massaluentojen ympärille, opiskelijoiden nimiä ei ehdi opetella koskaan eikä osan kasvojakaan opi muistamaan, tutkimuksen tekemiseen ei ole mitään mahdollisuuksia (ilman että allokoi tähän iltansa ja viikonloppunsa). Pahinta on, että hallinto jakaa opetettavat kurssit, jolloin ekspertiisi ei aina kohtaa kurssisisältöjä. Itse joudun vetämään syventävien opintojen jaksoa, johon minulla ei ole minkäänlaista pätevyyttä tai osaamista. (yliopisto A, kasvatustieteet, nro 19, nainen, alle 40 vuotta)

Näiden tutkija-opettajien voi katsoa sitoutuneen yliopiston palvelutehtävään kuuluvaan opetustyöhön (McInnis 2010, 149-150), mutta tämä sitoutuminen ei mahdollistanut heidän ohjautumistaan oman moraalisen kehyksensä mukaisesti vaalimaan myös muita heille tärkeitä asioita, kuten omaa ja perheen hyvinvointia. Samalla he eivät kokeneet hallitsevansa työtään akateemiseen eetokseen perinteisesti kuuluvan itsehallinnan ihanteen mukaisesti (McInnis 2010, 155).

Myös tutkimus kuului joidenkin tätä suhtautumistapaa edustaneiden vastaajien työtehtäviin. Tutkimustyötä tekevät katsoivat, ettei heillä työtahdin kiristymisen vuoksi ollut mahdollisuutta tehdä tutkimusta niin hyvin kuin he haluaisivat. Kiire voidaan nähdä työhön liittyvänä rakenteellisena ongelmana, joka vähentää työn merkityksellisyyden kokemusta (Salonen \& Tapani 2020). Tätä suhtautumistapaa edustaneet vastaajat katsoivat julkaisumääriin panostamisen ja "julkaisujen tuottamisen liukuhihnalta" johtavan siihen, että aikaa ei jäänyt "laadukkaan ja kauaskantoisen" tutkimuksen tekemiseen, minkä he puolestaan totesivat heikentävän kokemusta työn merkityksellisyydestä. Aika ei riittänyt ajattelulle ja luovuudelle, joita laadukkaan tutkimustyön tekeminen näiden vastaajien mielestä vaatisi. Tutkimustyötä tekevät tutkija-opettajat kuvasivat julkaisupaineen ja suurien opetusmäärien lisäksi painetta ulkoisen rahoituksen hankintaan. Tämän paineen kertoivat kokevansa raskaana varsinkin ne vastaajat, jotka eivät onnistuneet rahoituksen hankinnassa:

Arvostetaan lähinnä ulkopuolisen rahoituksen hankkimista ...Koko ajan kokee epäonnistumisen tunnetta kun ei rahoitusta onnistu saamaan. (yliopisto B, kasvatustieteet, nro 16, mies, yli 55 vuotta) 


\section{Toimintaedellytysten yleinen analysointi ja kritisointi}

Tätä suhtautumistapaa edustaneet tutkija-opettajat toivat kuvauksissaan esiin yliopistotyössä vallitsevia jännitteitä, kuten tutkimus- ja opetustyön merkityksellisyyttä heikentävää painetta ulkopuolisen rahoituksen hankkimiseen ja julkaisujen tuottamiseen nopealla tahdilla. He kuitenkin analysoivat näitä jännitteitä yleisellä tasolla sen sijaan, että olisivat kuvanneet niitä voimakkaina tai heidän omaa työn merkityksellisyyden kokemustaan uhkaavina. Akateemiselle eetokselle tyypillistä kollektiivisuutta ilmeni näiden vastaajien kuvauksissa siten, että monet heistä eivät käyttäneet minämuotoa, vaan puhuivat sen sijaan "meistä" tai esimerkiksi "tutkijoista" yliopistossa:

Kilpailu on koventunut rahoitushakujen suhteen, joista tutkijoiden työn jatkuminen monesti on täysin riippuvainen. Lisäksi myönnettyjen rahoitusten määrät ja kestoajat ovat pienentyneet. Tutkijan elämä on nykyään monesti elämistä tutkimusrahahausta toiseen. (yliopisto A, lääketiede tai biotieteet, nro 8, nainen, 40-55 vuotta)

Näiden vastaajien näkökulma vaihteli lähityöyhteisön tasolta valtakunnalliseen tiedepolitiikkaan ja globaaleihin kysymyksiin. He analysoivat monipuolisesti, mikä nykyisessä järjestelmässä ja yliopiston uudistuksissa on heidän mielestään myönteistä tai kielteistä kehitystä, eivätkä siten kuvailleet yliopistossa tapahtuneita muutoksia yksiselitteisesti joko hyvinä tai huonoina asioina. Jotkut vastaajat suhtautuivat yritysmäisen yliopiston odotuksiin ambivalentilla tavalla:

Arvostetaan tutkimusrahoitusta, mikä on ihan ymmärrettävää, mutta toisaalta mielestäni työn tuloksia mitataan hyvin kapea-alaisesti vain julkaisujen perusteella. Tämäkään ei riitä vaan entistä enemmän otetaan huomioon Jufo-luokitukset, toisin sanoen pian ei pelkkä vertaisarvioitu julkaisu riitä vaan pitää tavoitella 3. tason julkaisuja, mikä on lehtorin työssä haasteellista. En välttämättä itse halua olla mukana kierteessä, jossa iso osa työstä muodostuu rahoitushakemusten laadinnasta etenkin kun pieni osa saa rahoitusta. (yliopisto A, kasvatustieteet, nro 14, nainen, 40-55 vuotta)

Tämä vastaaja suhtautui melko ymmärtävästi yritysmäisen yliopiston asettamiin tavoitteisiin, kuten korkeatasoisissa tiedelehdissä julkaisemiseen ja tutkimus- 
rahoituksen hankintaan, mutta hän ei kuitenkaan pitänyt näihin tavoitteisiin pyrkimistä henkilökohtaisesti merkityksellisenä.

Vaikka tätä suhtautumistapaa edustaneiden tutkija-opettajien tapa kertoa työstään oli muita vastaajia objektiivisempi, sitä kuitenkin leimasi yliopistohenkilöstölle perinteisesti tunnusomainen kriittisyys, joka kohdistui erityisesti rahan arvostukseen, paineisiin hankkia ulkopuolista rahoitusta ja julkaisupaineisiin. Monet näistä vastaajista kritisoivat nykyisiä johtamisrakenteita, kontrollia, hierarkiaa ja byrokratiaa, jotka estävät itselle tärkeiden asioiden toteuttamista. Yksi vastaaja kuvasi kontrollin lisääntymistä opetustyössä seuraavasti:

Nykyisin on enemmän keskitettyä kontrollia sen suhteen, mikä katsotaan kannustettavaksi opetukseksi sisällön ja opetuskeinojen suhteen, mikä ei. Hallinnon korkeilta portailta tulevat suositukset ja määräykset ovat mielestäni joskus olleet sellaisia, että ne eivät ole perustuneet kokemuksiin ruohonjuuritason opettajana, vaan johonkin idealistiseen käsitykseen, joka ei heijasta ruohonjuuritason kokemuksia ja näkemyksiä. (yliopisto A, kielitieteet, nro 10, mies, yli 55 vuotta)

Tässä vastauksessa tulee esiin professionalismin mukainen ajatus, että käytännön toimijat tuntevat itse työnsä kompleksisuuden ja vaatimukset (Freidson 2001; Evetts 2013), minkä vuoksi heitä tulisi kuunnella työtä koskevia suosituksia ja määräyksiä laadittaessa. Tätä suhtautumistapaa edustaneet vastaajat esittivät kritiikkiä myös yliopistossa toteutettuja uudistuksia, "jatkuvia muutosprosesseja ja niihin liittyviä kokoustamisia", kohtaan. Hallinnon tehtävien nähtiin siirtyneen suurelta osin tutkimus- ja opetushenkilöstön harteille, minkä katsottiin vaikuttavan negatiivisesti tutkimuksen laatuun:

Hallinnon irtaannuttaminen yksiköistä ja hallintorakenteen uudistukset ovat kasanneet osan hallinnon tehtävistä tutkijoiden vastuulle, mikä hidastaa tieteellistä ja opetukseen liittyvää outputtia. Ulkopuoliset paineet luovat uhkia ja rajoittavat meidän mahdollisuuksia sekä pyrkivät ohjaamaan tutkimusta osin "nopeiden ratkaisuiden" suuntaan, mikä on lyhytkestoista ja kostautuu ajan mittaan. (yliopisto A, lääketiede tai biotieteet, nro 26, nainen, 40-55 vuotta) 


\section{Tyytyväisyys yliopistotyössä}

Tätä suhtautumistapaa edustaneet vastaajat kuvasivat yliopistoa työpaikkana myönteisessä valossa eivätkä tuoneet juurikaan esiin jännitteitä omien ja yliopiston arvojen välillä. He näkivät omat työskentelyedellytyksensä yliopistossa varsin hyvinä. Toisin kuin yritysmäisen yliopiston vastustus - suhtautumistapaa ja työssä kuormittuminen ja resurssipulasta kärsiminen -suhtautumistapaa edustaneet tutkija-opettajat, nämä vastaajat eivät kertoneet yliopiston vaativan ja painostavan heitä työskentelemään tietyllä tavalla, eivätkä he katsoneet yliopiston asettamien vaatimusten haittaavan merkityksellisyyden kokemista omassa työssään. Nämä vastaajat eivät ylipäätään juurikaan puhuneet heidän työlleen asetetuista vaatimuksista, vaan sen sijaan he kertoivat kokemastaan vapaudesta ja vaikutusmahdollisuuksista varsinkin omassa lähityöyhteisössään. Esimerkiksi yksi kasvatustieteitä edustava henkilö vastasi seuraavasti kysymykseen, joka koski hänen kokemiaan mahdollisuuksia toteuttaa itselle tärkeitä asioita omassa tieteenalayksikössä tai yliopistossa:

Työilmapiirimme on mielestäni hyvin vapaa. Voin täysin itsenäisesti päättää opettamiseni muodoista ja tavoitteista. Tutkimistani ei rajoita oikeastaan mikään. Vastaukseni on siis: erinomaisesti. (yliopisto A, kasvatustieteet, nro 21, mies, yli 55 vuotta)

Tämä vastaaja näytti kokevan, että hänellä on työssään riittävästi vapautta rakentaa työnsä merkityksellisyyttä omista lähtökohdistaan, mikä viittaa akateemiseen eetokseen liittyvään itsehallinnan ja autonomian ihanteeseen (McInnis 2010, 155).

Autonomian lisäksi tätä suhtautumistapaa edustaneet vastaajat kertoivat olevansa tyytyväisiä asioihin, jotka eivät liittyneet suoraan yliopiston perustyöhön eli tutkimukseen ja opetukseen vaan enemmänkin sosiaaliseen vuorovaikutukseen ja omaan lähityöyhteisöön. He olivat tyytyväisiä työnsä tarjoamiin oppimismahdollisuuksiin, kuten "asioiden jakamiseen tiedeyhteisössä", "oman tehtäväkuvan laajentumiseen" tai "yliopiston tarjoamiin väyliin päästä mukaan tapahtumiin ja projekteihin". Vastaajat nostivat myönteisinä asioina esiin myös työyhteisössä vallitsevan hyvän työilmapiirin, muiden luottamuksen omiin tekemisiin, saatavilla olevan tuen ja "professoreiden avoimuuden uusille ajatuksille ja ideoille". Yliopiston tai oman tieteenalayksikön kerrottiin arvostavan asiantuntijuutta, aktiivisuutta, yhteistyökykyisyyttä ja innokkuutta. Nämä eivät ole erityisesti yliopistolle tunnusomaisia 
ihanteita, vaan ne voisivat olla kannatettavia arvoja missä tahansa työyhteisössä. Nämä vastaajat katsoivat yliopistossa vallitsevien arvojen olevan sellaisia, joihin he itsekin halusivat sitoutua:

Minusta omassa yliopistossamme ja omassa tieteenalayksikössämme arvostetaan niitä asioita, joita pitääkin: laadukasta opetusta ja mahdollisuuksia tehdä hyvää perustutkimusta. (yliopisto B, kielitieteet, nro 2, nainen, 40-55 vuotta)

Tätä suhtautumistapaa edustaneista vastaajista ne, jotka toivat esiin yritysmäisen yliopiston tavoitteita, eivät pitäneet niitä ristiriitaisina omien tavoitteidensa tai arvojensa kanssa. Jotkut heistä puhuivat "huippututkimuksesta", ja yksi lääketiedettä edustaneista vastaajista piti hyvänä sitä, että "tutkimusalojen menestyksellisyys ohjaa arvostuksia ja painotuksia". Yritysmäisten tavoitteiden tuomisen yliopistoon saatettiin jopa nähdä luovan itselle uusia mahdollisuuksia työn merkityksellisyyden rakentamiseen:

Yliopistolain muutos vaikutti merkittävästi yliopistotoimintaan - ja monessa asiassa myös positiivisesti. Puuhastelu loppui ja suojatyöpaikka-mentaliteetti on hävinnyt. Näin ollen tavoitteellisuus ja herääminen mm. uusiin opetus- ja oppimismuotoihin sekä tutkimuksen profilointiin ovat avanneet uusia mahdollisuuksia toimintaan. (yliopisto B, lääketiede, nro 18, nainen, yli 55 vuotta)

Tätä suhtautumistapaa edustaneet vastaajat rakensivat työnsä merkityksellisyyttä monista aineksista. Heidän kuvauksissaan ei autonomian korostamista lukuun ottamatta ollut juurikaan viitteitä perinteiseen akateemiseen eetokseen. Näiden vastaajien oman moraalisen kehyksen voi tulkita sopineen melko mutkattomasti yhteen yritysmäisten tavoitteiden kanssa. Osa tätä suhtautumistapaa edustaneista vastaajista oli työskennellyt yliopistossa vasta vähän aikaa, joten he eivät olleet itse kokeneet yliopistotyössä ja sen puitteissa tapahtunutta muutosta. Heillä ei siten ollut vertailukohtaa, johon he olisivat peilanneet nykyisiä työskentelyolosuhteita. Kuten Archer $(2008,272)$ toteaa, managerialismin vahvuutena on, että se pystyy näyttäytymään "ainoana mahdollisena" kontekstina yliopistotyölle. Näin ollen varsinkin nuorempien tutkija-opettajien saattoi olla vaikeaa kyseenalaistaa sitä. 


\section{Itsenäinen ja vaikutusvaltainen toimijuus}

Tätä suhtautumistapaa edustavien tutkija-opettajien kuvauksissa korostui heidän selviytymisensä yliopistossa vallitsevien jännitteiden puitteissa oman toimintansa ja hallussaan olevien resurssien ansiosta. He pystyivät toimimaan yliopistossa siten, että jännitteet eivät juurikaan vaikuttaneet heidän omaan työhönsä ja heidän kokemaansa työn merkityksellisyyteen. Nämä vastaajat kuvasivat itseään muita vastaajia riippumattomammiksi yliopiston tarjoamista työnteon puitteista. He näyttivät uskovan, että heidän työskentelyedellytyksensä ja menestymisen mahdollisuutensa olivat suurelta osin itsestä kiinni, eikä yliopiston rakenteilla näyttänyt olevan heihin paljonkaan vaikutusta (ks. myös Tapanila ym. 2020). Näiden vastaajien kuvauksissa korostui itsenäisyys, jonka katsottiin edistävän työn merkityksellisyyden kokemusta: Yhden lääketiedettä edustaneen vastaajan sanoin mahdollisuus suunnitella ja toteuttaa itse työhön liittyviä asioita "antaa motivaatiota työn tekemiseen, koska lopputulos riippuu silloin hyvin pitkälti itsestäni".

Monet tätä suhtautumistapaa edustaneet vastaajat näkivät yritysmäisen yliopiston arvot ja tavoitteet melko samansuuntaisina omien pyrkimystensä kanssa. Jotkut kuitenkin kuvasivat jännitettä niiden välillä, mutta he pystyivät lieventämään sitä yhdistelemällä työssään erilaisia arvoja ja tavoitteita:

[Arvostetaan] täydentävän rahoituksen saamista, ahkeraa julkaisemista, tutkintojen tuottamista. Nyky-yliopistossa arvostetaan toimintaa, joka tuo taloudellista tulosta. Tutkimuksen laatu on toissijaista. Tässä tilanteessa joutuu tasapainottelemaan suunnitellessaan omaa työtä: yhtäältä pyrkiä mahdollistamaan itselle tärkeä ja laadukas tutkimus täydentävän rahoituksen kautta ja toisaalta pyrkiä olemaan tuottelias julkaisemalla yhdessä kollegoiden kanssa ja ekologisesti. (yliopisto B, kasvatustieteet, nro 8, nainen, yli 55 vuotta)

Tätä suhtautumistapaa edustaneista vastaajista suuri osa teki tutkimuspainotteista työtä. Heidän vastauksissaan korostui ulkoinen rahoitus, jota he olivat onnistuneet hankkimaan tutkimukselleen. Rahoituksen katsottiin turvaavan itselle työn tekemisen edellytykset. Esimerkiksi yksi kielitieteilijä totesi, että jos hän onnistuu rahanhaussa, hän voi luoda itselleen hyvän työskentely-ympäristön. Sen lisäksi, että rahoitusta saadessaan nämä vastaajat pystyivät vastaamaan yliopiston odo- 
tuksiin ulkoisen rahoituksen hankkimisesta, itse hankittu rahoitus toi heille itsenäisyyttä ja mahdollisuuksia vaikuttaa omaan työhön.

Rahoituksen hankkimisen lisäksi nämä vastaajat toivat esiin myös muita heihin itseensä liittyviä asioita, jotka ovat parantaneet heidän mahdollisuuksiaan rakentaa työnsä merkityksellisyyttä. Tällaisia tekijöitä olivat muun muassa oman tutkimuskokemuksen karttuminen ja osaamisen kehittyminen, myönteisen palautteen tai palkintojen saaminen, verkostoituminen, "lobbaaminen yliopiston ulkopuolella" ja "hyvien ideoiden" esittäminen. Näiden vastaajien voi tulkita nähneen omien saavutustensa suojaavan heitä yritysmäisen yliopiston kuormittavilta vaatimuksilta. Osa näistä vastaajista kertoi olevansa vaikutusvaltaisessa asemassa yliopistossa, kuten professorina, tutkimusryhmän johtajana tai oppiaineen vastuuhenkilönä. Asemansa ansiosta heillä oli runsaasti liikkumavaraa ja hyvät mahdollisuudet toteuttaa itselleen tärkeitä asioita työssään. He pystyivät myös itse vaikuttamaan työlle asetettuihin vaatimuksiin ja olemaan siten vähemmän alttiita yritysmäisen yliopiston tutkija-opettajiin kohdistamille paineille:

Pystyn toteuttamaan [itselleni tärkeitä asioita] varsin vapaasti. Oppiaineen vastuuhenkilönä päätän tutkimuksen ja opetuksen linjaukset varsin pitkälle itse.

(yliopisto B, lääketiede, nro 22, mies, yli 55 vuotta)

Monille tämän suhtautumistavan edustajista oman uran edistäminen oli tärkeä työssä tavoiteltava asia. He kertoivat tavoittelevansa pysyvää työsuhdetta tai tohtorin tutkintoa, tai tähtäsivät "tenure track -polun kautta professuuriin". Jotkut heistä sanoivat tekevänsä työtä pääasiassa itselleen tai tutkimusryhmälleen yliopiston sijaan. Näin ollen heidän suhteensa yliopistoon saattoi olla melko löyhä, vaikka he omaa uraa edistääkseen joutuivat tavoittelemaan myös yliopiston heiltä vaatimia asioita. Tässä suhtautumistavassa on samoja piirteitä kuin Dowdin ja Kaplanin (2005) kuvaamassa yrittäjämäisessä tutkijatyypissä sekä Ylijoen ja Henrikssonin (2017) tunnistamassa akateemisen freelancerin uratarinassa, joissa omavaraisuus ja itsenäisyys ovat yliopistoyhteisön jäsenyyttä tärkeämpää. Tällaista suhtautumistapaa edustavien voi nähdä myös kuuluvan akateemisen maailman menestyjiin, joiden asemaa yritysmäiselle yliopistolle tyypilliset suoritusten mittaamistavat voivat vahvistaa entisestään (Kallio ym. 2016). 


\section{Pohdinta}

Olen tarkastellut tässä artikkelissa eri tieteenaloja edustavien tutkija-opettajien tapoja suhtautua yritysmäisen yliopiston arvostamiin asioihin ja sen heille asettamiin vaatimuksiin sekä näiden suhtautumistapojen ilmentämiä työn merkityksellisyyden rakentamiseen liittyviä jännitteitä. Tutkija-opettajat rakensivat aineistossani työnsä merkityksellisyyttä puheensa kautta aineksista, joita on tarjolla heidän narratiivisessa ympäristössään (Gubrium \& Holstein 2008). Tätä prosessia ohjasi moraalinen kehys; se auttoi tutkija-opettajia valitsemaan asioita, joita he haluavat kannattaa ja joista he voivat rakentaa työnsä merkityksellisyyttä (Taylor 1989).

Tunnistamani suhtautumistavat ilmensivät erilaisia jännitteitä yliopistotyössä. Yritysmäisen yliopiston vastustus - suhtautumistapaa edustaneiden tutkija-opettajien kuvaama jännite perustui heidän ja yritysmäisen yliopiston arvomaailmojen erilaisuuteen. He rakensivat työnsä merkityksellisyyttä aineettomista asioista, jotka eivät saaneet tunnustusta määrälliseen mittaamiseen keskittyvässä yritysmäisessä yliopistossa. Työssä kuormittuminen ja resurssipulasta kärsiminen -suhtautumistapaa edustaneiden tutkija-opettajien esiin tuoma jännite pohjautui heidän työssään kohtaamiin ylimitoitettuihin vaatimuksiin, joiden vuoksi he eivät voineet työskennellä ja rakentaa työnsä merkityksellisyyttä oman moraalisen kehyksensä mukaisesti. Toimintaedellytysten yleinen analysointi ja kritisointi -suhtautumistavassa tutkija-opettajat eivät yksiselitteisesti kannattaneet tai vastustaneet yritysmäisen yliopiston arvoja ja vaatimuksia, eivätkä he siten kertoneet kokevansa selvää työn merkityksellisyyden rakentamiseen liittyvää jännitettä. Tyytyväisyys yliopistotyössä -suhtautumistavassa tutkija-opettajien arvot sen sijaan sopivat hyvin yhteen yritysmäisen yliopiston heiltä odottamien asioiden kanssa, ja he pystyivät kokemaan merkityksellisyyttä työssään. Itsenäinen, vaikutusvaltainen toimijuus -suhtautumistapaa edustaneet tutkija-opettajat kykenivät oman toimintansa tai asemansa ansiosta välttämään mahdollisen ristiriidan yritysmäisen yliopiston arvojen ja omien arvojensa välillä, eikä jännite tällöin uhannut heidän mahdollisuuksiaan rakentaa työnsä merkityksellisyyttä.

'Yritysmäisen yliopiston vastustus' ja 'työssä kuormittuminen ja resurssipulasta kärsiminen' -suhtautumistavoissa, joissa ilmeni voimakas jännite omien ja yritysmäisen yliopiston arvostamien asioiden välillä, nousi esiin muita suhtautumistapoja yhtenäisempi akateeminen eetos: niissä työn merkityksellisyyden rakentaminen 
pohjautui sitoutumiseen yliopiston palvelutehtävään, totuuden tavoitteluun ja laatuun, joka määritettiin profession sisältä käsin eikä yritysmäisen yliopiston arviointijärjestelmien kautta. Akateemiseen eetokseen kiinnittyminen voi ilmentää Kallion ja kollegoiden $(2016,703)$ ajatusta, että kokiessaan olevansa uhattuina ihmiset tulevat tietoisemmaksi omista sitoumuksistaan. Edellä mainitun kahden suhtautumistavan edustajat voivat kohdatessaan yritysmäistyneessä yliopistossa arvostuksen ja tunnustuksen puutetta olla taipuvaisia tukeutumaan perinteiseen akateemiseen eetokseen. Tutkimuksessani selvimmin tuli esiin juuri arvostuksen puutteesta johtuva jännite, joka näytti siis olevan yhteydessä vahvempaan akateemiseen eetokseen sitoutumiseen.

Tyytyväisyys yliopistotyössä - suhtautumistapaa ja itsenäinen, vaikutusvaltainen toimijuus - suhtautumistapaa edustaneet vastaajat puolestaan rakensivat työnsä merkityksellisyyttä moninaisista asioista, jotka eivät olleet ristiriidassa yritysmäisen yliopiston vaatimusten kanssa. Nämä asiat olivat usein yhteydessä yksilölliseen oppimiseen ja urakehitykseen, jotka kytkeytyvät yksilön omiin intresseihin (ks. myös Rosewell \& Ashwin 2019) perinteiseen akateemiseen eetokseen kuuluvan palvelutehtävän sijaan. Ne saattoivat liittyä myös työyhteisöön, sosiaaliseen vuorovaikutukseen ja rahoituksen hankkimiseen, jotka eivät kuulu yliopiston varsinaisiin perustehtäviin vaan ovat luonteenomaisempia muunlaisten organisaatioiden - kuten yritysten - toiminnalle. Näihin tavoitteisiin sitoutuminen voi viitata akateemisen eetoksen merkityksen heikkenemiseen tutkija-opettajien henkilökohtaisia valintoja ohjaavassa moraalisessa kehyksessä, mikäli he eivät koe suurta jännitettä suhteessa yritysmäiseen yliopistoon ja sen vaatimuksiin.

Koska aineistoni tutkija-opettajat rakensivat työnsä merkityksellisyyttä monenlaisten arvojen ja ihanteiden pohjalta, tutkimukseni tulokset eivät tue näkemystä, että tutkija-opettajat olisivat selvästi sitoutuneet tieteenaloja yhdistävään akateemiseen eetokseen (vrt. Kallio 2015, 89-90). Saman tieteenalan ja tieteenalayksikönkin sisällä ilmeni monenlaisia suhtautumistapoja, joten akateeminen eetos ei välttämättä yhdistänyt edes samassa tieteenalayksikössä työskenteleviä tutkija-opettajia. Ainoastaan yritysmäisen yliopiston vastustus -suhtautumistapaa esiintyi selvästi eniten yhdessä tutkimuksen kohteena olleista tiedekunnista. Kyseessä oli kasvatustieteiden tiedekunta, mikä voi viitata siihen, että kasvatuksellisten arvojen hallitsemassa narratiivisessa ympäristössä oli tarjolla muita tiedekuntia enemmän aineksia työn merkityksellisyyden rakentamiseen yhtenäisen eetoksen pohjalta. Kyseistä tiede- 
kuntaa edustaneet tutkija-opettajat toivat myös muita enemmän esiin kokemastaan arvostuksen puutteesta johtuvaa jännitettä.

Suhtautumistapojen erilaisuus voi kertoa paitsi yliopistomaailman moniarvoistumisesta myös sen jakautumisesta voittajiin ja häviäjiin (ks. myös Ylijoki \& Ursin 2013). Eroja suhtautumistavoissa näyttivät tuottavan opetus- ja tutkimustyön resurssien epätasainen jakautuminen sekä tutkija-opettajien erilaiset vaikutusmahdollisuudet ja kokemukset arvostuksen saamisesta työssään. Niillä, joilla on käytössään enemmän resursseja ja vaikutusvaltaa, oli usein myös enemmän autonomiaa työssään ja siten paremmat mahdollisuudet työnsä merkityksellisyyden rakentamiseen. Ne, jotka joutuvat työssään kärsimään resurssien puutteesta, eivät välttämättä pysty toimimaan perinteisen akateemisen eetoksen mukaisesti, johon kuuluu työn tekeminen opiskelijoita ja yhteiskuntaa palvellen. Yliopisto todennäköisesti kykenisi toteuttamaan yhteiskunnallista palvelutehtäväänsä monipuolisemmin, jos arvostusta osoitettaisiin ja resursseja jaettaisiin tasapuolisemmin eri tieteenaloilla ja erilaisissa positioissa tehtävälle yliopistotyölle.

\section{Kirjoittaja}

\section{Katriina Tapanila}

KM, KTM, projektitutkija, Tampereen yliopisto

sähköposti: katriina.tapanila@tuni.fi

\section{Kirjallisuus}

Apo, S. (1995) Naisen väki: tutkimuksia suomalaisten kansanomaisesta kulttuurista ja ajattelusta. Helsinki: Hanki ja jää.

Archer, L. (2008) The new neoliberal subjects? Young/er academics' constructions of professional identity. Journal of Education Policy 23 (3), 265-285. https://doi.org/10.1080/02680930701754047

Becher, T. (1989) Academic tribes and territories. Milton Keynes: Open University Press. 
Björn, I., Saarti, J. \& Pöllänen, P. (2017) Yliopistot talousvetureiksi: Suomalaiset yliopistot ja yliopistojen tuottama sivistys tehostamistalouden kohteena. Teoksessa T. Eskelinen, H. Harjunen, H. Hirvonen \& E. Jokinen (toim.) Tehostamistalous. Jyväskylä: SoPhi, 140-162.

Carvalho, T. \& Videira, P. (2019) Losing autonomy? Restructuring higher education institutions governance and relations between teaching and non-teaching staff. Studies in Higher Education 44 (4), 762-773. https://doi.org/10.1080/03075079.2017.1401059

Chown, A. (1996) Post-16 teacher education, national standards and the Staff Development Forum: Time for openness and voice? British Journal of In-Service Education 22 (2), 133-150. https://doi.org/10.1080/0305763960220203

Clark, B. R. (1998) Creating entrepreneurial universities: Organizational pathways of transformation. Guildford: Pergamon.

Cohen-Meitar, R., Carmeli, A. \& Waldman, D. A. (2009) Linking meaningfulness in the workplace to employee creativity: The intervening role of organizational identification and positive psychological experiences. Creativity Research Journal 21 (4), 361-375. https://doi.org/10.1080/10400410902969910

Dowd, K. O. \& Kaplan, D. M. (2005) The career life of academics: Boundaried or boundaryless? Human Relations 58 (6), 699-721. https://doi.org/10.1177\%2F0018726705057156

Eskola, J. \& Suoranta, J. (2014) Johdatus laadulliseen tutkimukseen. Tampere: Vastapaino.

Evetts, J. (2013) Professionalism: Value and ideology. Current Sociology Review 61 (5-6), 778-796. https://doi.org/10.1177\%2F0011392113479316

Freidson, E. (1999) Theory of professionalism: Method and substance. International Review of Sociology 9 (1), 117-129. https://doi.org/10.1080/03906701.1999.9971301

Freidson, E. (2001) Professionalism: The third logic. Lontoo: Polity Press. Gordon, G. \& Whitchurch, C. (2010) Academic and professional identities in higher education: The challenges of a diversifying workforce. Abingdon: Routledge. 
Gubrium, J. \& Holstein, J. (2008) Narrative ethnography. Teoksessa N. HesseBiber \& P. Leavy (toim.) Handbook of emergent methods. New York: The Gilford Press, 241-264.

Hakala, J. (2009) The future of the academic calling? Junior researchers in the entrepreneurial university. Higher Education 57 (2), 173-190. https://doi.org/10.1007/s10734-008-9140-6

Heikkinen, H. L. T. (2001) Narratiivinen tutkimus - todellisuus kertomuksena. Teoksessa J. Aaltola \& R. Valli (toim.) Ikkunoita tutkimusmetodeihin. Jyväskylä: PS-kustannus, 116-132.

Henkel, M. (2005) Academic identity and autonomy in a changing policy environment. Higher Education 49 (1/2), 155-176.

Hänninen, V. (1999) Sisäinen tarina, elämä ja muutos. Tampere: Tampereen yliopisto.

Kallio, T. (2015) Ammattilaisbyrokratiat tehokkuuden aikakaudella: Tasapainoilua asiantuntijaeetoksen ja tehokkuuspaineiden välillä. Tampere: Tampere University Press.

Kallio, K.-M., Kallio, T., Tienari, J. \& Hyvönen, T. (2016) Ethos at stake: Performance management and academic work in universities. Human Relations 69 (3), 685-709. https://doi.org/10.1177\%2F0018726715596802

Kankaanpää, J. (2013) Kohti yritysmäistä hyöty-yliopistoa: Valtiovallan tahto Suomessa vuosina 1985-2006 ja kokemukset kolmessa yliopistossa. Turun yliopiston julkaisuja, Sarja C, osa 369. Turku: Turun yliopisto.

Kaukonen, E. \& Välimaa, J. (2010) Yliopistopolitiikan ja rakenteellisen kehittämisen taustoja. Teoksessa H. Aittola \& L. Marttila (toim.) Yliopistojen rakenteellinen kehittäminen, akateemiset yhteisöt ja muutos. RAKE-yhteishankkeen (2008-2009) loppuraportti. Opetusministeriön julkaisuja 2010:5. Opetusministeriö, Helsinki, 13-20.

Kogan, M., Moses, I. \& El-Khawas, E. (1994) Staffing higher education - Meeting new challenges. Lontoo: Jessica Kingsley.

Kolsaker, A. (2008) Academic professionalism in the managerialist era: A study of English universities. Studies in Higher Education 33 (5), 513-525. https://doi.org/10.1080/03075070802372885

Laajalahti, A. (2015) Tutkijoiden attribuutiot: Mistä vuorovaikutusosaaminen tai sen puute johtuu? Aikuiskasvatus 35 (1), 16-27. 
May, D. R., Gilson, R. L. \& Harter, L. M. (2004) The psychological conditions of meaningfulness, safety and availability and the engagement of the human spirit at work. Journal of Occupational and Organizational Psychology 77 (1), 11-37. https://psycnet.apa.org/doi/10.1348/096317904322915892

McInnis, C. (2010) Traditions of academic professionalism and shifting academic identities. Teoksessa G. Gordon \& C. Whitchurch (toim.) Academic and professional identities in higher education. New York: Routledge, 147-165.

Parsons, T. (1939) The professions and social structure. Social Forces 17 (4), 457-467. https://doi.org/10.2307/2570695

Rhoades, G. (1998) Managed professionals. Albany: State University of New York Press.

Rinne, R., Jauhiainen, A., Simola, H., Lehto, R., Jauhiainen, A. \& Laiho, A. (2012) Valta, uusi yliopistopolitiikka ja yliopistotyö Suomessa: Managerialistinen hallintapolitiikka yliopistolaisten kokemana. Turku: Suomen kasvatustieteellinen seura.

Rosewell, K. \& Ashwin, P. (2019) Academics' perceptions of what it means to be an academic. Studies in Higher Education 44 (12), 2374-2384. https://doi.org/10.1080/03075079.2018.1499717

Salonen, A. O. \& Tapani, A. (2020) Palkkatyön merkityksellisyys: Ammatillisen koulutuksen opetus- ja ohjaushenkilöstön kokemuksia työstä. Työelämän tutkimus 18 (1), 30-46. https://doi.org/10.37455/tt.90571

Shepherd, S. (2018) Managerialism: An ideal type. Studies in Higher Education 43 (9), 1668-1678. https://doi.org/10.1080/03075079.2017.1281239

Siekkinen, T. (2019) The changing relationship between the academic profession and universities in Finnish higher education. Jyväskylän yliopisto, Koulutuksen tutkimuslaitos. Tutkimuksia 35. Jyväskylä: Jyväskylä University Press.

Slaughter, S. \& Leslie, L. (1997) Academic capitalism. Lontoo: The Johns Hopkins University Press.

Subotszky, G. (1999) Alternatives to the entrepreneurial university: New modes of knowledge production in community service programs. Higher Education 38 (4), 401-440. https://doi.org/10.1023/A:1003714528033

Tapanila, K. (2020). Akateemisen työn merkityksellisyys ja yliopiston muuttuvat vaatimukset. Aikuiskasvatus 40 (1), 36-51. https://doi.org/10.33336/aik.91046 
Tapanila, K., Siivonen, P. \& Filander, K. (2020) Academics' social positioning towards the restructured management system in Finnish universities. Studies in Higher Education 45 (1), 117-128. https://doi.org/10.1080/03075079.2018.1539957

Taylor, C. (1989) Sources of the self: The making of the modern identity. Cambridge: Cambridge University Press.

Ylijoki, O.-H. (1998) Akateemiset heimokulttuurit ja noviisien sosialisaatio. Tampere: Vastapaino.

Ylijoki, O.-H. (2005) Academic nostalgia: A narrative approach to academic work. Human Relations 58 (5), 555-576. https://doi.org/10.1177\%2F0018726705055963

Ylijoki, O.-H. (2014) University under structural reform: A micro-level perspective. Minerva 52, 55-75. https://doi.org/10.1007/s11024-014-9246-1

Ylijoki, O.-H. \& Henriksson, L. (2017) Tribal, proletarian and entrepreneurial career stories: Junior academics as a case in point. Studies in Higher Education 42 (7), 1292-1308. https://doi.org/10.1080/03075079.2015.1092129

Ylijoki, O.-H. \& Ursin, J. (2013) The construction of academic identity in the changes of Finnish higher education. Studies in Higher Education 38 (8), 1135-1149. https://doi.org/10.1080/03075079.2013.833036 


\section{Katriina Tapanila}

The construction of the meaningfulness of work and tensions in the transforming university

The construction of meaningfulness of work is guided by a moral frame, which helps individuals to choose issues to commit to. This individual moral frame can be linked with an ethos characteristic of the profession. In this study, I focus on the academic profession whose working conditions have been shaped by recent university reforms. I ask how the academics representing education, medicine, bioscience, and linguistics position themselves towards the issues valued by the entrepreneurial university and the demands it makes of the academics. I also ask what kind of tensions these positionings manifest related to the construction of the meaningfulness of work. My data consist of academics' descriptions of their stances towards their work and the recent changes in universities, which were collected by using a thematic writing methodology. I identified five distinct positionings in the data: 1) resistance to the entrepreneurial university, 2) being overloaded at work and suffering from a lack of resources, 3) general analysis and criticism of the working conditions, 4) satisfaction with the academic work, and 5) independent, powerful agency. The differences in the positionings seemed to originate from the uneven distribution of resources in teaching and research duties, different opportunities for the academics to wield influence, and varying experiences of being valued at work. 